\title{
Ruins and city. \\ Procedure suggestion for the Imperial Forums of Rome
}

\author{
Valeria Marcenac, María José Ballester Bordes, Luis Bosch Roig, \\ Carlos Campos Gonzalez, Ignacio Bosh Reig \\ Instituto Universitario de Restauración del Patrimonio. \\ Universitat Politècnica de Valencia, Valencia, Spain \\ E-mail: marceval@pra.upv.es; mabalbor@pra.upv.es; luibosro@pra.upv.es; \\ ccampos@pra.upv.es; ibosch@pra.upv.es
}

\begin{abstract}
The actual area of the Imperial Forums is presented as a big urban void in which the scale of the city has been lost. A "no man's land", inhospitable, to which you could assign the qualifying of "non-place". A huge and fragmented "archaeological park" in which the observer is not able of relate the rests and recognise the trace of the ancient forums. This problems have been adressed within the framework of the "Workshop of Conservation and Intervention" of the MCPA Master of the UPV, in which have been suggested differente strategies, both of search of the sewn of the city, and of the recognition of the different historical stratums existing on the place. To the same extent, this topic has been an international contest object, on which the proposal we have presented comes from a "modern" attitude, that helps us going beyond the evocative power of the ruin, or from its value as a referent from the past. An attitude which seeks to inhabit the ruin, occupy and settle it with architectures that renew its value, they are commited with the past and the present, and they guarantee their future presence. In this sense, the wanted and searched condition of "presence", is not as supported by the recovery of what have existed as it is by the ability of the intervention by accepting the transformations which have happened throughout history, introducing in turn a new stratum that besides answering the current needs, strengthen its statement as architecture. And all of that, urban regeneration is searched through the recuperation of the city's scale loss.
\end{abstract}

Keywords: Ruins, urban void, urban regeneration, scale of the city, presence.

Introduction: to recover the scale of the city

We find ourselves in a place full of history, as a result of the addition of the layers of the Roman, Paleochristian, medieval, Renaissance and modern cities that, after the sventramenti from the 30s, has lost large urban sectors, turning into an immense archaeological site, in the centre of Rome.

To intervene on it, is a certainly complex territory, wherein the feelings can emerge above the rationality, and it makes it more attractive and suggestive, as it connects with the depths of our being, in a permanent internal struggle between what we wish and what we consider appropriate.

But, ourwesternculture, decidedlyinfluenced by Piranesi's drawings and engravings, and by the writings and paintings from the nineteenth century romantic travelers, induces us to assess its evocative power above other considerations, running the risk of replacing the reason by the admiration, setting up a look back at the past, as a basis for its permanence.

However, the desired and sought condition of "permanence", does not depend as much on the recovery of what existed before, as in the capacity of the intervention to assume the 


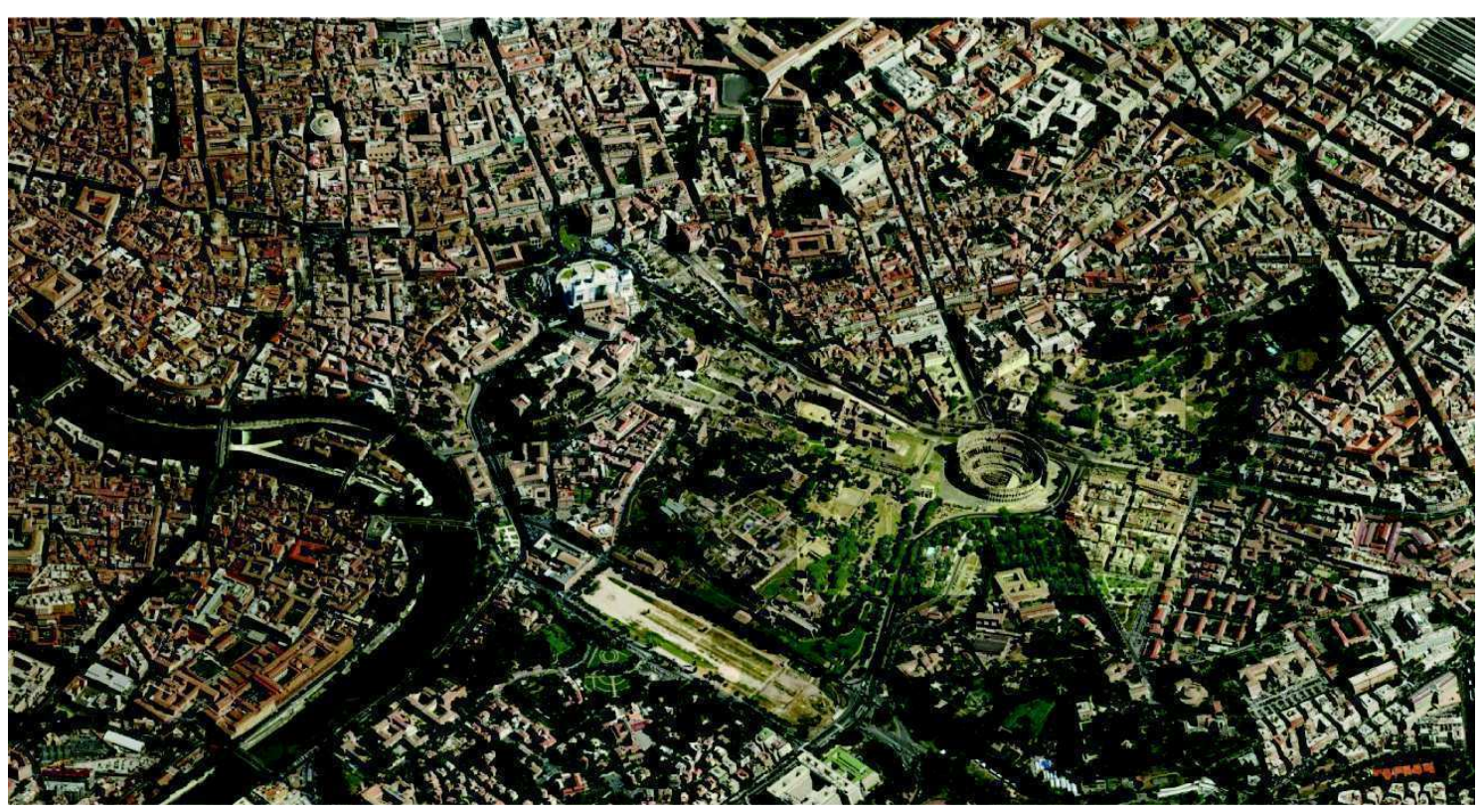

Figure 1.

Urban void in the centre of Rome

transformation that culture itself has introduced in the course of history. And therefore, it will be its statement as architecture what will guide it to new interventions that will extend its existence indefinitely.

\section{Methodology}

In this process, it should be underlined as relevant, to understand the intervention as an unfinished work, in progress, and consequently, opened to new actions.

This is a "modern" attitude, that helps us to go beyond its evocative power, or its value as a reference from the past, as Alos Riegl once said, to attribute to the ruin the "artistic will", to be source of inspiration to the observer, and therefore to stimulate the imagination and creativity. In this way, following Harbison, it will be able to construct new meanings, and thus to raise the promise of the uncertainty and the unexpected.

This capacity of spontaneity and unpredictability is reinforced, if we take into account, in accordance with Walter Benjamin, that the technical capacity of reproductionimitation, leads us to question its value of authenticity.

Ultimately, it should be understood that the action on the ruin must be such that by living, occupying and colonising it with new architectures, renews its value, commits with the past and the present, and projects it to the future, with more confidence in its permanence.

And we raise that from a critical look, developing a historic analysis and a profound recognition of the site, that will allow us to carry out a precise architecture, simple and abstract, where applying the right design tools, we will be able to conjugate time and history, to manage the scale, to determine the whole from the fragments, and therewith to construct the city. (Figure 1)

\section{Analysis}

From the analysis done, it is worth to mention that the current area of the Via dei Fori Imperiali, is presented as a big urban void where the scale of the city has been lost. A "no man's land", inhospitable, to which you could assign the qualifying of "non-place". But we can neither describe it as an "archaeological park", since the observer is not able to link the remains and recognise the trace of the Fori Imperiali.

From here, there have been recognised three strands of values to recover and enhance, such as: 


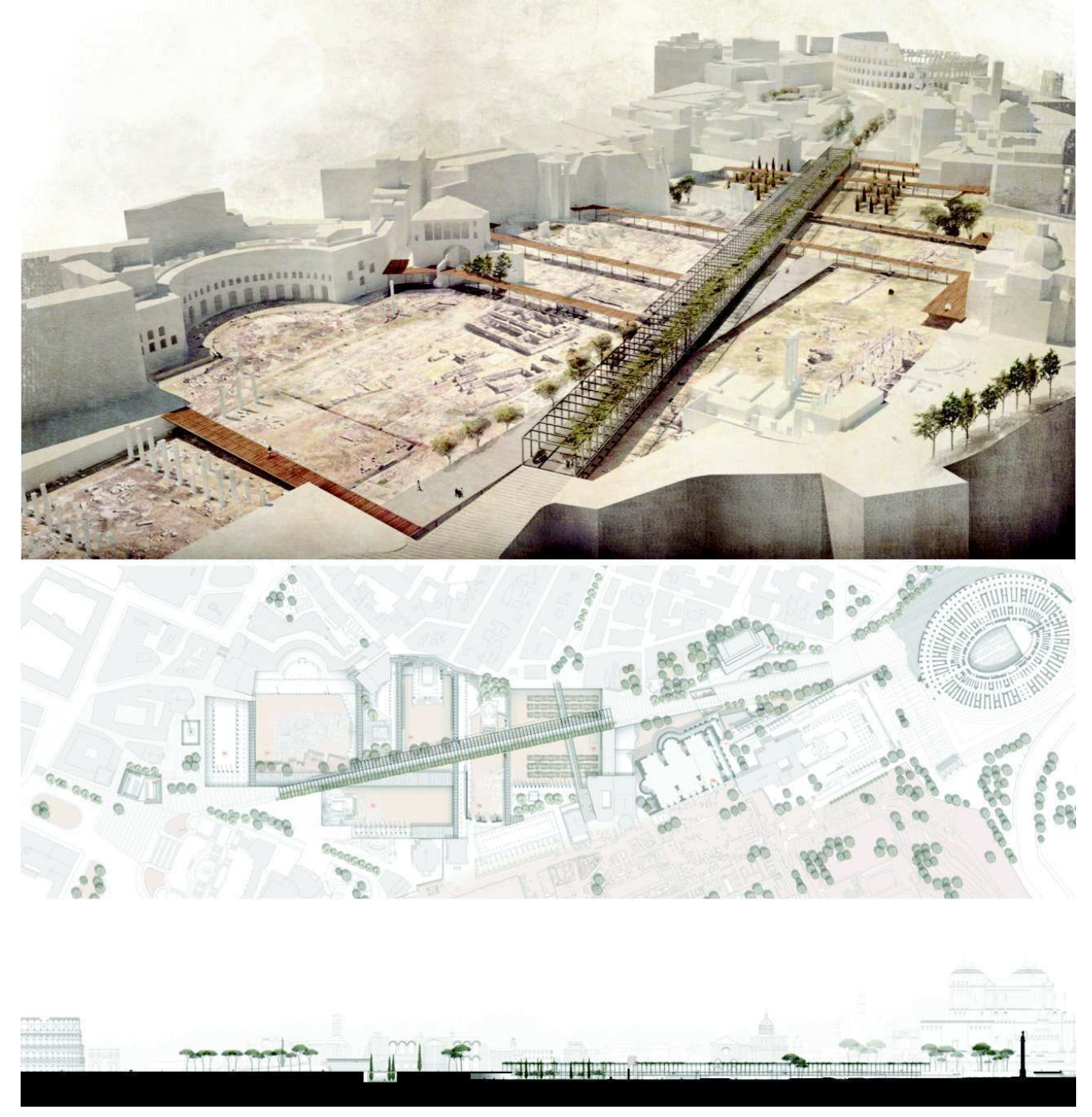

Figure 2.

General view of the intervention; Floor plan of the whole intervention; general section of the proposal

-The first one, to preserve, as a key urban view of Rome, the unparalleled perspective obtained in the 30's, with the aperture of the Via dei Fori Imperiali, between Piazza Venezia and Colosseo.

-The second one, to introduce an order system between the current fragments of the ruins, that will allow the recognition and definition of the original spaces of the Forums.

-The third one, and most specially, to search for the recovery of the scale of the city, with the objective of obtaining an urban space, that combines both the activity of the city and the enjoyment of the pedestrian and the tourist.

\section{Proposals}

New urban linear axis

For that purpose, it is proposed a new axis west-east, from Piazza Venezia to Colosseo, as a safe and comfortable path, that levitates over the Forums, and allows the viewing of the archaeological space beneath the way, as well as its dimensional and compositional comprehension.

To achieve it, we propose six transverse walkways, with a double purpose: to stablish north-south connection city paths, and to 

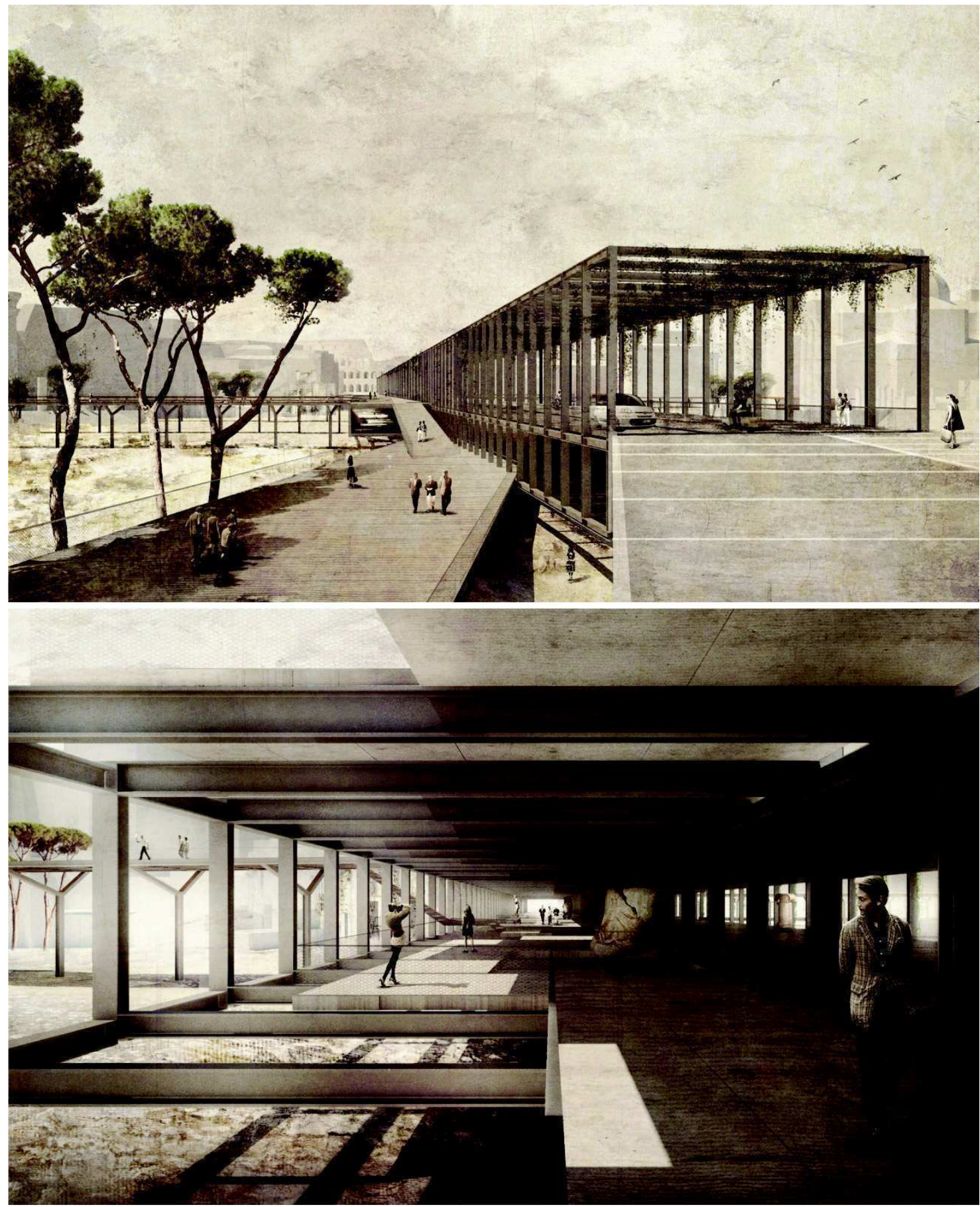

Figure 3.

3D view of the intermediate level and the connection to the axis

delimit the dimension of the Forums, enabling its legibility, through the definition of its original limits.

The west-east path (Piazza Venezia Colosseo), is defined by the new axis, as a built urban space that as 8 meters high shading structure, partially covered with vegetation, aims to introduce a reference element on the site, and to stablish the environmental conditions that allow the visitor to feel protected by the scale of the city.

This shading structure, starts in front of the Foro di Traiano, and crosses the Forums of Augusto, Nerva and della Pace, and ends at the East edge, leaving visible the rests of the Tempio della Pace, that are not dug yet. 


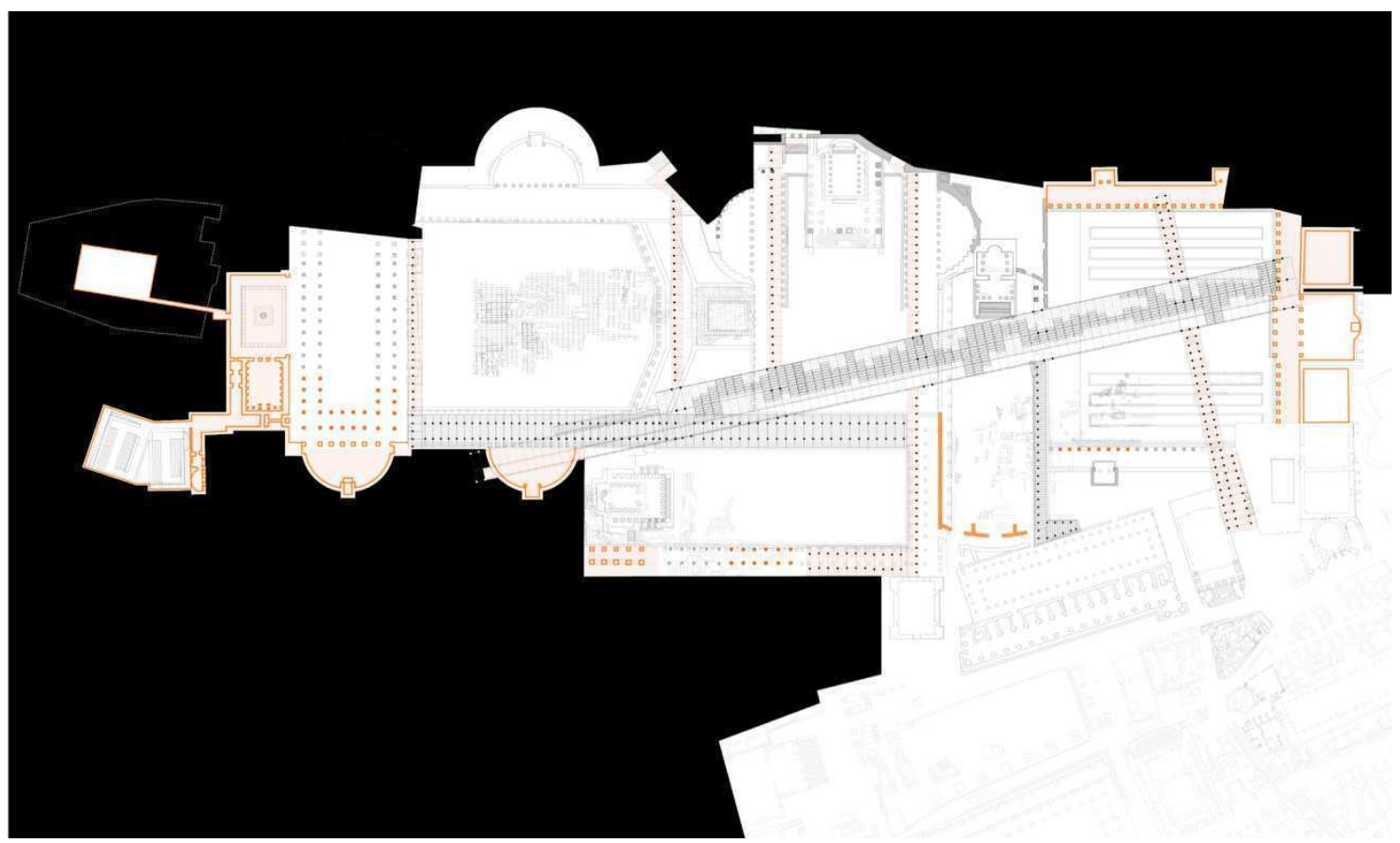

Figure 4.

General floor plan at the intermediate level

This place will conserve the existing wooded areas until the completion of the archaeological excavation, and it will have new wooded areas, taking advantage of the interstices between the Forums and in the areas originally landscaped at the Tempio della Pace, where it is planned to evoke the ancient species.

This new urban axis, begins at Piazza Venezia as a paving, that defines a pedestrian space, in front of the remains of the Adriano's Auditorium, stablishing a walkway-path that allows to contemplate them form the above, and a ramp that gives access to the lower level.

At the city level, the void of the Auditorium's ruins is protected by a bench parapet on its perimeter. (Figure 2)

At the Roman level, it is showed the will of stablishing a connection between the remains of the Temple of the Forum of Adriano and the Auditorium of Adriano, which in turn is raised as an access or exit from the archaeological level to the city level.

The section reinforces the idea of the connection at the lower level, and at the same time transmits a minimal intervention approach at the Auditorium of Adriano. (Figure 3)
The definition of the limits of the Roman Forums:

The provision north-south of the 5 meters wide transverse walkways, is the adequate to define the void space of the different Forums, in such a way that allows to be recognized by the observer who contemplates the archaeological remains. In addition to this important objective, the aforesaid walkways collect the pedestrian flows from the north part of the city, defined by via Alessandrina, Piazza del Grillo, Arco di Pantani and via della Madonna del Monti, and crossing the new urban axis, channel them to the south, givin access to the Chiesa dei Santi Luca e Martina, Curia Iulia and Basilica Emilia.

The substantial number of pedestrians at via Cavour, is solved by a wider walkway $(8 \mathrm{~m})$, and with a perpendicular layout to the new axis, so that crossing it establishes a connection with the Tempio de Antonino e Faustina and the building beside the Basilica of Magencio.

On the other hand, the definition of the south limit of the Foro di Nerva and Tempio della Pace, is relied on the essential reconstruction of the south wall, and the new wooded area (cypresses and olive trees). 

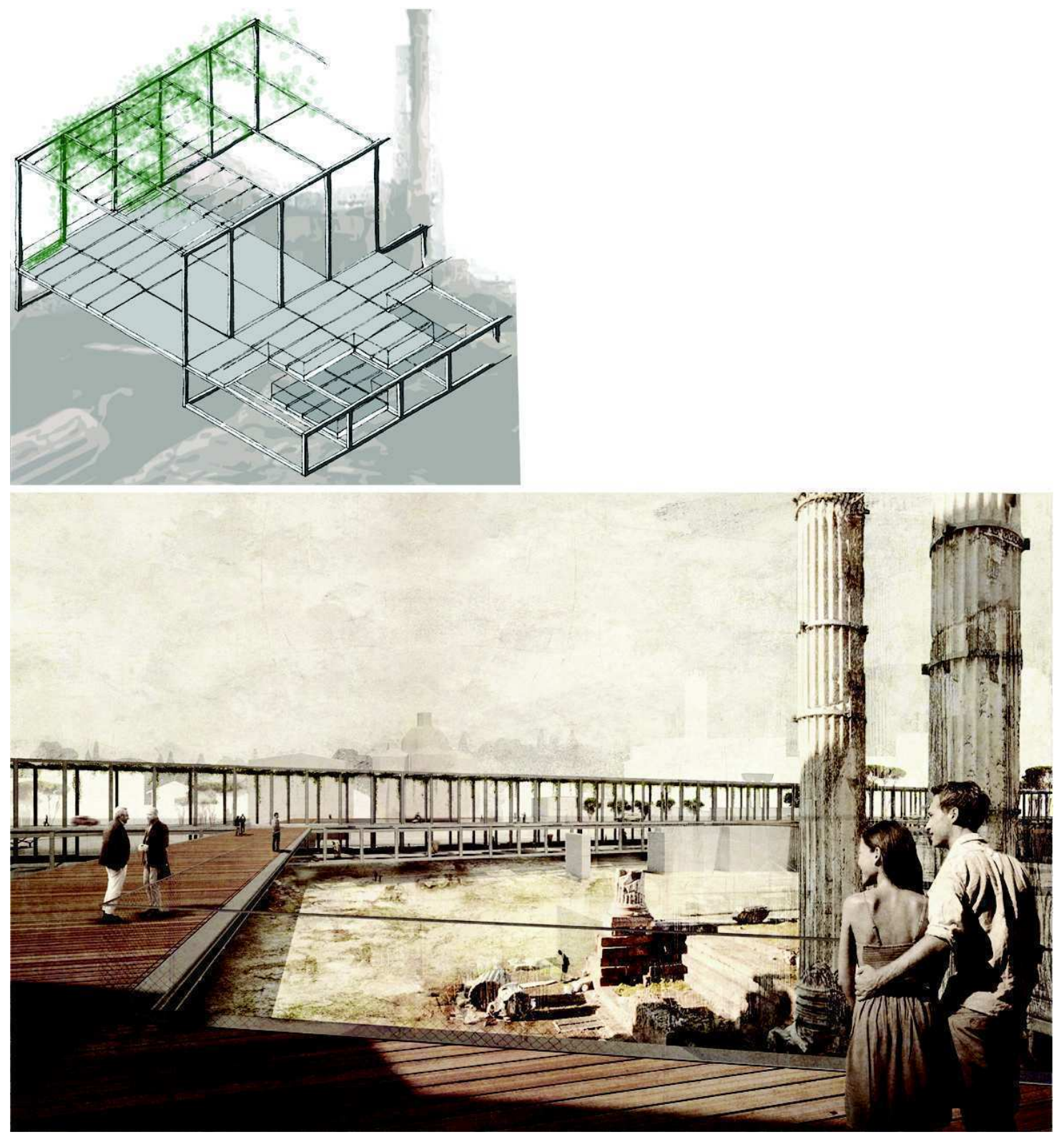

Figure 5.

Structural detail of the axis; 3D view of the new axis flying through the Forum

The south limit of the Forum of Traiano and Nerva, and the north limit of the Forum of Cesar, are defined by a lineal walkway, westeast, located at the intermediate level.

This is one of the topics that were explored from the beginning, evaluating the connection possibilities of the transverse walkways with the new longitudinal axis, so that intermediate levels could appear between the city and the archaeological ones.

This topic has been defined by an intermediate plane, that establishes the south and north limits of some Forums and introduces new uses and paths, by connecting with the lower part of the axis and thus allowing to observe the remains from a $3-4 m$ height. (Figure 4)

This space, can be used to build, through prefabricated elements, platforms for various uses, under the shade of the axis, such as a linear development of an antiquary that could compile and organize the various archaeological remains that are scattered at the roman imperial level. 
This intermediate level, is extremely versatile, so that it could being built in accordance with the archaeological digging, or the evolution of the society, what is linked with the concept of opened architecture and in progress, aforementioned.

If we focus attention on the archaeological remains level, it should be highlighted at least two relevant topics: firstly, the rhythmic sequence of the new walkways pillars, that define the limits of the Forums, by evoking the intercolumniation of the original arcade.

The construction of the new linear axis:

And secondly, the strategic arrangement of the only six points of support of the bearing structure of the new west-east urban linear axis, conceived to bridge big spans, and thus pass through the forums, crossing its whole dimension $(60 \mathrm{~m})$, avoiding intermediate pillars that could confuse to the observer. (Figure 5)

This structure is formed by three vierendeel girders, placed in a longitudinal direction, and connected through laminated profile girders.

Both viernendeel girders placed in the south side, emerge from the city level, creating a shading structure, while the one placed in the north side, only descends towards the archaeological level, providing support for the intermediate plane. (Figure 5)

The new axis, at the city level, has at the south side the shading structure with a $14 \mathrm{~m}$ fixed width, where can live together pedestrians and public and emergency transport. And, at the north side, has a variable dimension space, with $10 \mathrm{~m}$ maximum width, acting as walking and stay platforms, where there will be arranged the explanatory boards of the spaces to be contemplated.

These platforms pass through the north sector medieval archaeological remains, what will allow to adequate over time the aforementioned excavation, and they will be built with variable depths, according to the necessities, following once again the concept of an open and in progress architecture.

This is one of the topics that where explored from the beginning, searching to coordinate the necessary and slow archaeological excavation with the delimitation of the new elements that will shape the urban space created by the intervention.

The archaeological excavation:

To carry out the project, the archaeological intervention of the Imperial Forums is organised in the following sequential phases:

1st Phase: removal and disassembly of the successive layers to a depth of around $1.5 \mathrm{~m}$, of the Via dei Fori Imperiali area involved.

2nd Phase: Archaeological excavation in a longitudinal trench to a depth of 1.5 more meters, from the beginning of the Foro di Traiano to the Basilica Massenzio, for the installation of the three Vierendeel girders that form the main structure of the project.

3rd Phase: Archaeological excavation for the realization of pile foundation, down from the seven support points where the main structure of the new axis rests.

The excavation of these two phases will follow an inverted pyramid system, which will allow integrating the remains of the different historical stages.

4th Phase: Once the assembly of all structural elements is completed, an extensive excavation will begin over all those spaces still to be excavated, coordinated with the construction of the elements proposed directly linked with the excavation, such as the intermediate plane, the linear axis north side platforms, or the construction of certain parts of the walkways.

The new museum:

Returning to the proposal, the urban linear axis is extended in front of the ancient Velia Hill, where the new museum is placed, across a new lower square, located at the level of the lobby of the new Metropolitan station, and continues as a pavement up to the Colosseo square.

This square, is constituted as an access space to the Imperial Forums, ascending by the via Venere Felice, sidestepping the temple of Venere e Roma up to the wall of the Basilica Massenzio, where the access control to the Forums and Museum is located. A simple onelevel construction, with the necessary services, located at the level of the Basilica Massenzio, connects through escalators and lifts with 

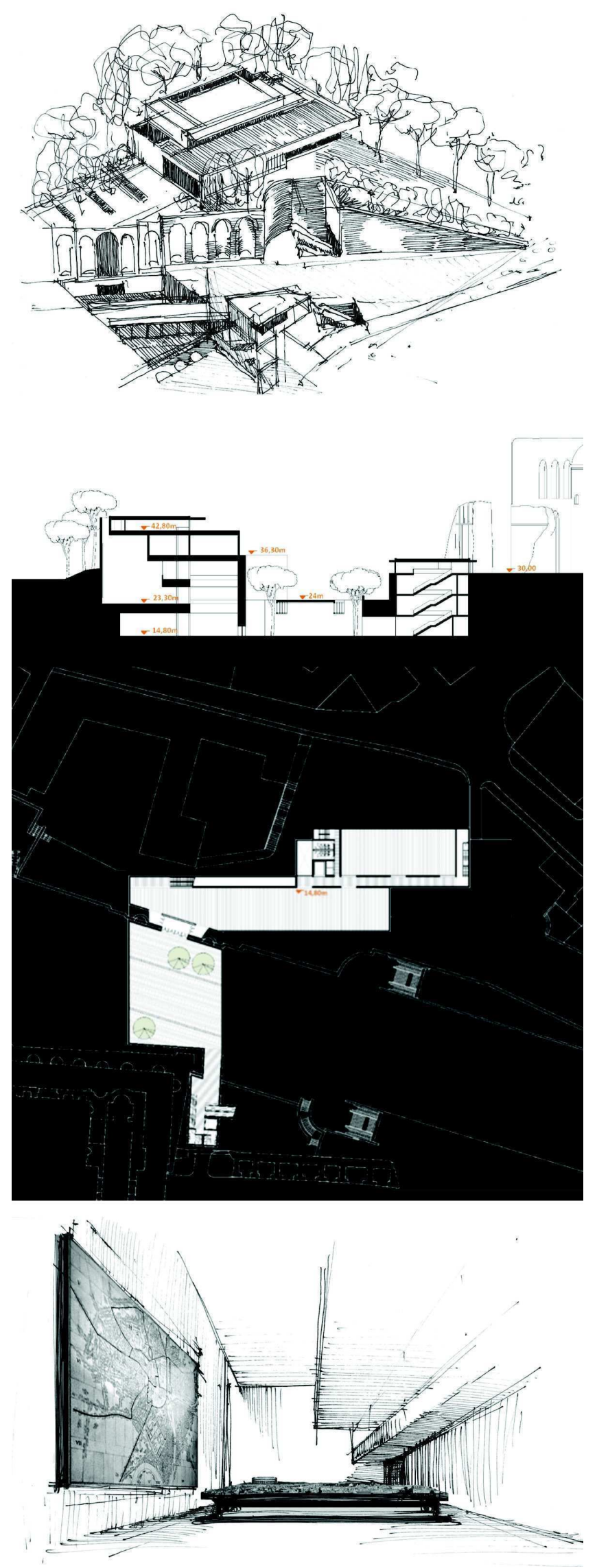

Figure 6.

External perspective of the museum, with two access; Floor plan; section and perspective of the museum inner space 
the new lower square that connects with the museum $15 \mathrm{~m}$ further down.

Thus, the Museum architecture extends at both sides of the new axis at Via del Fori Imperiali, connected through the aforementioned lower square.

The main building of the museum is locates on the north side, as volumes that emerge beside the Muñoz wall, up to reached the upper level of the aforementioned ancient Velia hill. (Figure 6)

The inner space of the museum is articulated according to three systems: the overlapping of horizontal spaces, acting as exhibition strata; the insertion of large vertical spaces that creates cross views; and the provision of an upward linear path, with escalators, that acting as a backbone, connects the different spaces.

The loading and unloading access for the exhibition works, is located in the rear side of the museum, from the Via del Colosseo, at the first floor below the street.

On the floor above the Velia hill, it is located the second museum access, reached through a wooded walk upward from the Colosseo square.

And on the next floor, it is located the cafeteria, in a magnificent belvedere that allows contemplating the Colosseo, the Basilica Massenzio and the extension of the forums.

The museum's architecture intends to be morphologically simple, giving priority to the landscape, to the sense of the ancient hill and the existing trees. (Figure 6)

Inside, profound visual relations are pursued, an upward exhibition path, that starting in the depth earth (Roman stratum), emerges up to the top of the Velia.

There is placed the main space of the museum, where the model of the Imperial Rome and the Forma Urbis are exhibited, that enlightened by a skylight, will infuse to the space a dramatic sense.

The key elements of the museum project are: understanding the exposed item as the focus; highlight the versatility, simplicity and concealment of the display system; and use of natural and artificial light, either directed, raking or frontal, highlighting the exposed item.
Consequently, the exhibition of new didactic material such as plans, projections, videos, models... is considered through large sizes that produced immersive spaces.

\section{Conclusion}

With the intervention, the landscape that defines the area of the forums transmutes, introducing a new spatial reference system that impregnates the place with a gentle order, allowing structuring the current non-place, and turning it into a series of interlocking spaces, and humanised, and thus recovering the scale of the city.

Finally, the authors of this report, want to reflect the importance of the teamwork developed on this labour, that has allowed a profound debate, without which the proposal made would not have been possible.

\section{References}

Bosch, Ll.; Marcenac, V.; Bosch, I. "La intervención en la capilla de los condes de Fuensaldaña. Estudio de un diálogo ejemplar entre antiguo y nuevo". En Blanco. pp. 64 72. 2016.

Bénjamin, W. La obra de arte en la época de su reproductibilidad técnica.

Grau, M.; Bosch, I. "San Carlino alle Quattro Fontane: ampliamento e modifiche settecentesche al progetto borrominiano". Disegnare. Idee immagini. pp. 22 - 33. 2016.

Bosch, I. "Architektura bliskiej relacji". ARCHITEKTURA. pp. 42 - 49. 2016.

Lizondo, L.; Santatecla, J.; Martínez, S.; Bosch, I. "La influencia de la arquitectura efímera en la arquitectura construida. El caso de Mies van der Rohe". ACE: Architecture, city and environment. 24, pp. 78 - 99. 2014.

Riegl, A. El culto moderno a los monumentos: Caracteres y origen. Visor Libros, 1987. $\left(1^{\circ}\right.$ ed. 1903).

Roig, M. Pilar; Bosch, I.; y otros. "Cielo, arte y espiritualidad". pp. 99 - 108. Institut Valencià d'Art Modern, 2013

Salvador, N.; Lizondo, L.; Bosch, I. "Las condiciones de vida de las colonias de Hidroeléctrica Española S.A. ¿Politicas 
sociales o control sobre los empleados?" VI Congreso para la Conservación del Patrimonio Industrial y la Obra Pública en España. pp. 100 - 110. Madrid, 2013.

Lizondo, L.; Martínez, S.; Santatecla, J.; Bosch, I. "De los concursos a las exposiciones; del fotomontaje a la técnica del papel pintado". EGA Revista de Expresión Gráfica Arquitectónica. pp. 35 - 45. 2013

Bosch, Ll.; Herráez, J.; Denia, J.; Navarro, P.; Bosch, I. "Structural reinforcement of a historic bridge to ensure stability by laser - guided drilling". Journal of Cultural Heritage. 1, pp. 1 - 9. 2012.

Bosch, I. "La ruina como valor añadido en el patrimonio. El non finito". Revista: Ingeniería y Territorio, 2011.

Bosch, I.; Roig, P.; Navarro A.; Bosch, L. "Interventi sui ponti storici Trinidad e Serranos a Valencia Work on the historic Trinidad and Serranos bridges in Valencia". Disegnare, Idee immagini. Nº42, 2011. 